\title{
Automatyzacja i robotyzacja procesu montażu i spawania profili walcowanych na przykładzie urządzenia Steel Beam Assembler or Welder - cześć 2
}

\author{
Automation and robotics \\ of assembly and welding processes \\ of rolled sections on an example \\ of the Steel Beam Assembler or Welder device \\ - part two
}

\section{Streszczenie}

Artykuł podejmuje zagadnienia związane z budową i wdrożeniem zrobotyzowanych urządzeń do uzbrojenia i spawania profili walcowanych na przykładzie maszyny "Steel Beam Assembler or Welder" (SBA) firmy Zeman \& Co. Pokazuje praktyczne możliwości wykorzystania w produkcji oraz trudności funkcjonowania urządzenia, które związane są z coraz większym skomplikowaniem i złożonością projektowanych konstrukcji stalowych. Analizuje techniki i metody wykorzystywane przez SBA przy prefabrykacji konstrukcji stalowych.

Artykuł skupia się na opisie budowy, zasadzie działania, sposobie programowania oraz parametrach i zakresie zastosowania urządzenia Steel Beam Assembler or WeIder. Podejmuje próbę określenia kierunków rozwoju maszyn do uzbrojenia i spawania profili walcowanych oraz problemów i barier na jakie napotykają ich konstruktorzy.

Słowa kluczowe: robot, robotyzacja, proces spawania

\section{Abstract}

The article deals with the issues connected with a structure and implementation of robotized devices used to arm and weld rolled sections on an example of the 'Steel Beam Assembler or Welder' (SBA) by Zeman \& Co company. It shows practical possibilities in the production use, and difficulties of functioning the device. Difficulties relate to an increase of complex designs of steel constructions. The article also analyses techniques and methods used in the prefabrication of steel constructions by the SBA device.

The article focuses on the description of a structure, rules of operating, ways of programming and a range of the Steel Beam Assembler or Welder use. It tries to describe the ways of the development of machines used to arm and weld rolled sections, as well as problems and barriers which the constructors meet.

Keywords: robot, robotics, welding process

Dr hab. inż. Jacek Słania prof. PCz - Politechnika Częstochowska, mgr inż. Roman Dziędzioł - ZEKON Sp. z o.o. Ruda Śląska. 


\section{Wstęp}

Konstruktorzy firmy Zeman \& Co podjęli się jako jedni z pierwszych na świecie, zadania zbudowania urządzenia do automatycznego uzbrojenia i spawania profili walcowanych o nazwie "Steel Beam Assembler or WeIder" (SBA). Artykuł opisuje wyniki ich pracy, trudności na jakie można napotkać przy budowie tego typu urządzenia, jak funkcjonuje w warunkach normalnej eksploatacji w toku produkcji, a także jak wygląda programowanie i nadzór spawalniczy nad tym urządzeniem [5].

\section{Opis urządzenia}

SBA jest zintegrowanym, zrobotyzowanym systemem montażowym i spawalniczym, który pozwala na kompleksowe wytwarzanie elementów konstrukcji stalowych. Urządzenie jest w stanie samodzielnie uzbroić i pospawać elementy konstrukcji stalowych bez udziału człowieka za pomocą zestrojonych i zaprogramowanych robotów, które wykorzystując odpowiednie wymienne narzędzia mogą zamontować i pospawać blachy we właściwych miejscach profili gorąco walcowanych lub kształtowników spawanych. Wszystko to odbywa się przy udziale czujników pomiarowych, skanerów, przenośników i obrotników. Urządzenie działa szybko, precyzyjnie, efektywnie i jest skonstruowane tak, żeby można było wytwarzać zarówno produkty seryjnie jak i pojedyncze elementy z szeroko różniących się składników.

Dzięki wysokiemu poziomowi automatyki, SBA wymaga minimalnych nakładów siły roboczej, a personel obsługujący maszynę nie potrzebuje żadnej specjalistycznej wiedzy.

\section{Budowa urządzenia}

Urządzenie Steel Beam Assembler or Welder zbudowane jest z zintegrowanych, współpracujących ze sobą części, tworzących maszynę zdolną do wyprodukowania gotowych elementów konstrukcji stalowych.

SBA zawiera następujące podzespoły:

- szafa z układem zasilającym,

- pulpit sterujący,

- stół załadunkowy dla elementów dokładanych do profilu głównego,

- stół magazynowy profili głównych z przenośnikiem poprzecznym,

- samotok,

- skaner laserowy AMBO wraz z kamerą,

- portale chwytające i pozycjonujące profil główny,

- robot dokładający elementy do profilu głównego za pomocą magnesów, oraz wykonujący operacje podgrzewania palnikiem propanowo-tlenowym,

- zasobnik z magnesami,

- portal spawalniczy główny (Master) odpowiedzialny za pomiar laserowy, spawanie oraz cięcie plazmowe,

- portal spawalniczy pomocniczy (Slave) odpowiedzialny za pomiar laserowy i spawanie,

Portale spawalnicze zarówno Master jak i Slave składają się z robota IRB 140 firmy ABB oraz źródła prądu TransPulsSynergic 5000 firmy Fronius.

- zasobnik narzędziowy zawierający uchwyt spawalniczy i palnik plazmowy,

- urządzenie do czyszczenia łuski uchwytu spawalniczego,

- urządzenie do kalibracji uchwytu spawalniczego,

- urządzenie do obracania blach,

- stół rozładunkowy.

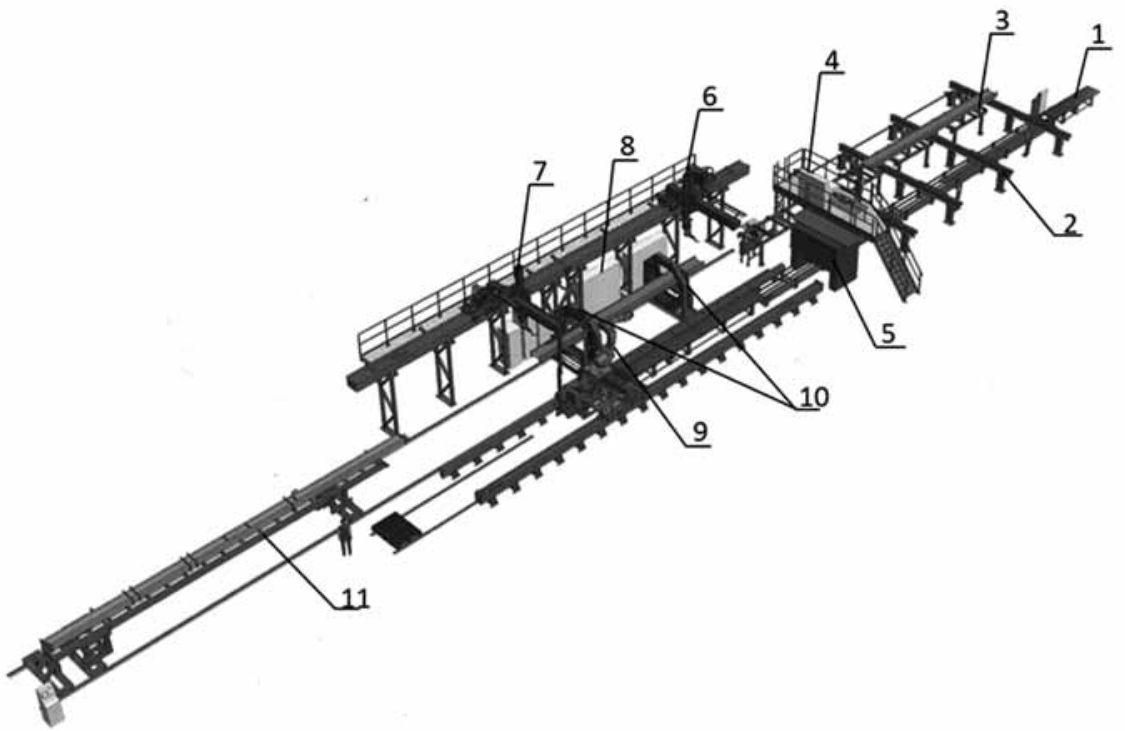

Rys. 1. Budowa urządzenie SBA: 1 - stół załadunkowy elem. dokładanych, 2 - stół magazynowy z przenośnikiem poprzecznym, 3 - samotok, 4 - pulpit sterujący, 5 - skaner laserowy AMBO, 6 - portal spawalniczy główny (Master), 7 - portal spawalniczy pomocniczy (Slave), 8 - szafy zasilające, 9 - robot dokładający elementy, 10 - portale chwytająco - pozycjonujące, 11 - stół rozładunkowy [1]

Fig. 1. A structure of the SBA device - a general view: 1 - a loading table of precise elements, 2 - a storage table with a cross conveyor, 3 - a roller table, 4 - a control desk, 5 - the laser scanner AMBO, 6 - the main welding gantry (Master), 7 - a support welding gantry (Slave), 8 - a power cubicle, 9 - a robot providing elements, 10 - gripping-positioning gantries, 11 - an unloading table [1] 


\section{Proces programowania}

Sercem urządzenia SBA jest pakiet oprogramowania „Pro-FIT” opracowany przez firmę Zeman \& Co. składający się z różnych modułów (okien). W procesie programowania wykorzystuje się kolejno poszczególne okna i zakładki, krok po kroku przechodząc kolejne etapy do stworzenia i wygenerowania konkretnego programu, według którego urządzenie wyprodukuje dany element zgodny z projektem.

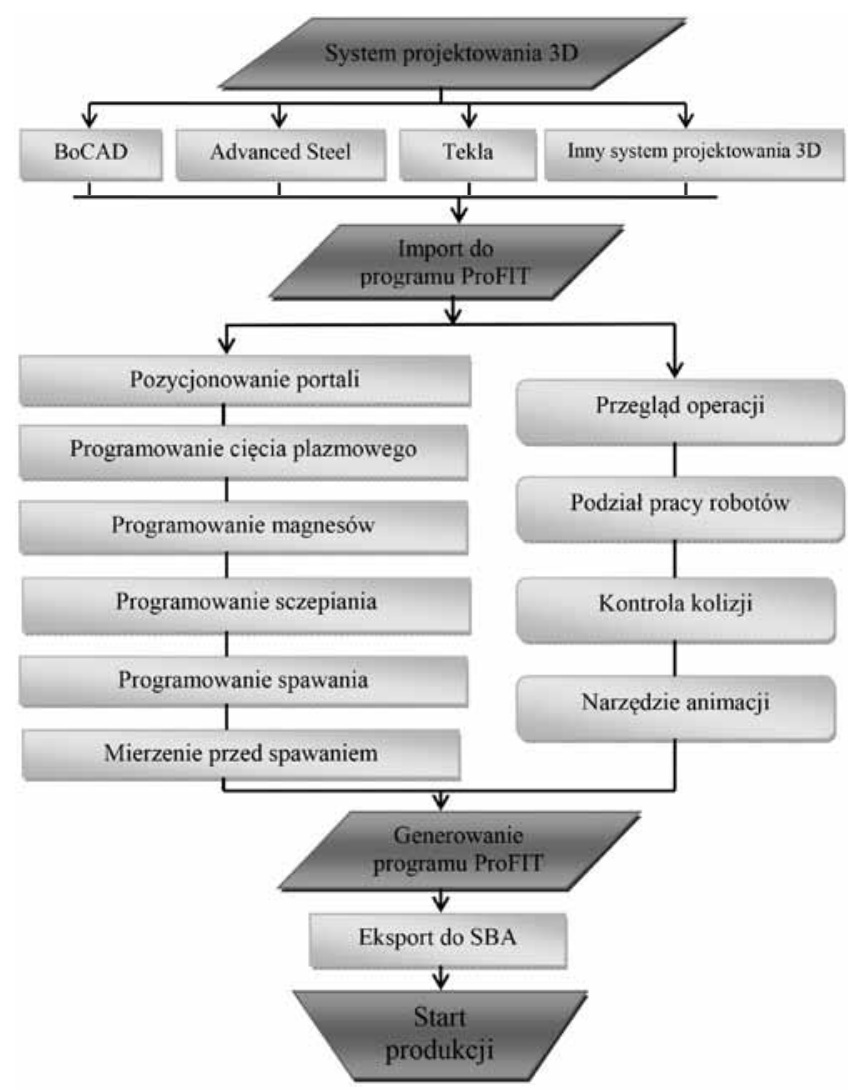

Rys. 2. Schemat blokowy procesu programowania SBA [1]

Fig. 2. A block diagram of a programming process of the SBA [1]
Proces programowania rozpoczyna się od zaimportowania modelu 3D konstrukcji stalowej przeznaczonej do wytworzenia z programu do projektowania. Po zaimportowaniu modelu z okna „Podglądu części” programista wybiera dany element, na który chce przygotować program. Po wyborze w oknie podglądu pojawia się widok na perspektywę 3D danego elementu, gdzie program sygnalizuje, które elementy są możliwe do dołożenia zaznaczając je kolorem zielonym, a których dołożyć nie można kolorując je na żółto (rys. 3).

Kolejnym krokiem jest usunięcie z programu elementów zaznaczonych na żółto (te zostaną dołożone przez monterów po zakończeniu pracy SBA). Po tej czynności programista wyznacza punkt "0" belki na jej początku, który będzie służył urządzeniu, jako punkt bazowy do wszystkich pomiarów przy montażu i spawaniu (rys. 4).

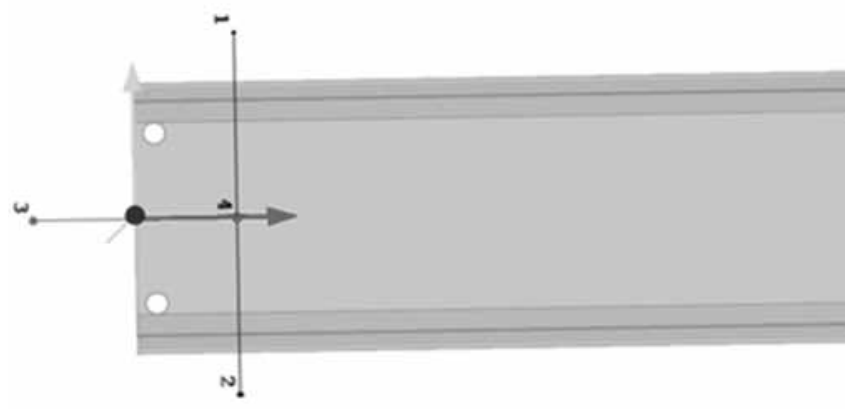

Rys. 4. Wyznaczenie punktu „0” (początek układu współrzędnych)[2] Fig. 4. Determining null point (the beginning of a co-ordinate system) [2]

Następnym zadaniem jest ustawienie portali czyli elementów chwytających i pozycjonujących główny profil w odpowiednich położeniach (zakolorowane pola na rys.5). Trzeba tu zwrócić uwagę na warunki brzegowe, czyli minimalne i maksymalne odległości między osiami portali (nie mogą na siebie zachodzić), na odległość między portalem a końcem belki, na środek ciężkości, a także na umiejscowienie elementów montowanych do belki np. żebra.

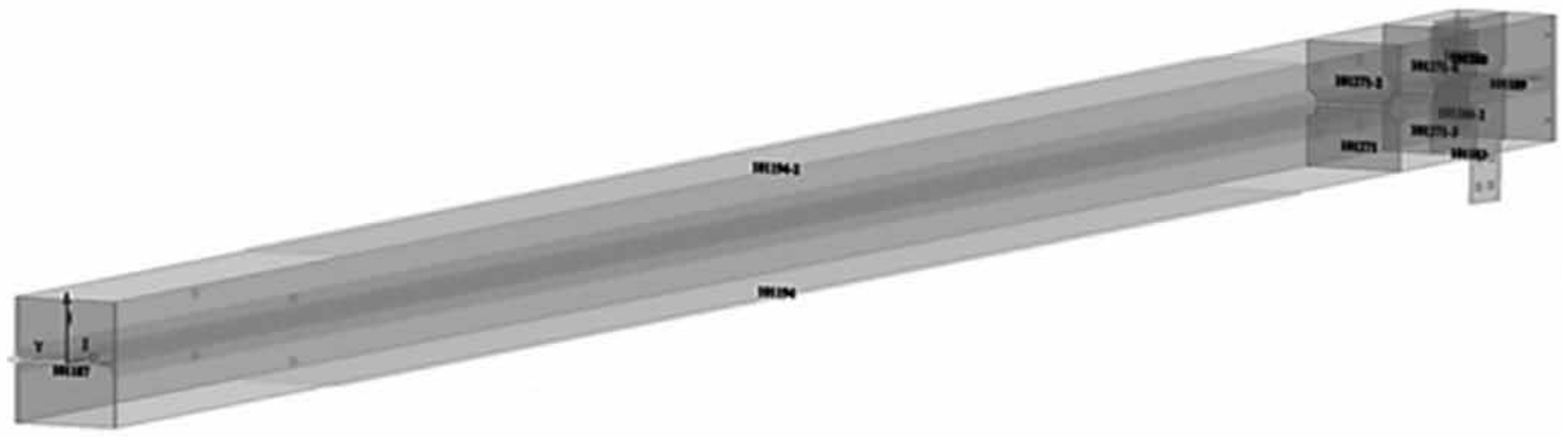

Rys. 3. Widok 3D zaimportowanego elementu [2]

Fig. 3. A 3D view of an imported element [2] 


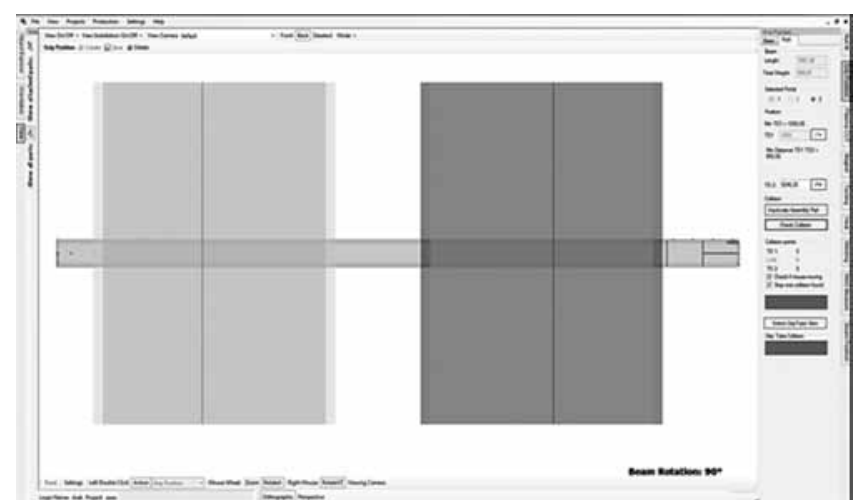

Rys. 5. Pozycjonowanie portali (elementy chwytające profil główny) [2] Fig. 5. Positioning of gantries (the main gantry gripping elements) [2]

Kolejnym krokiem jest programowanie cięcia plazmowego. Jeżeli jest wymagane wycinanie półek profili, wycinanie otworów, bądź ukosowanie profili, to wtedy programista zadaje robotowi odpowiednie koordynaty do wykonania pomiaru cięcia (pomiar laserowy) w celu wyznaczenia linii cięcia, oraz kąt ustawienia palnika plazmowego w przypadku wykonania ukosowania. Jak widać na poniższym rysunku program pozwala na bieżąco kontrolować programowane czynności. Pokazuje jak profil będzie wyglądał po cięciu i w jakim położeniu będzie znajdował się palnik podczas tej operacji (rys.6)

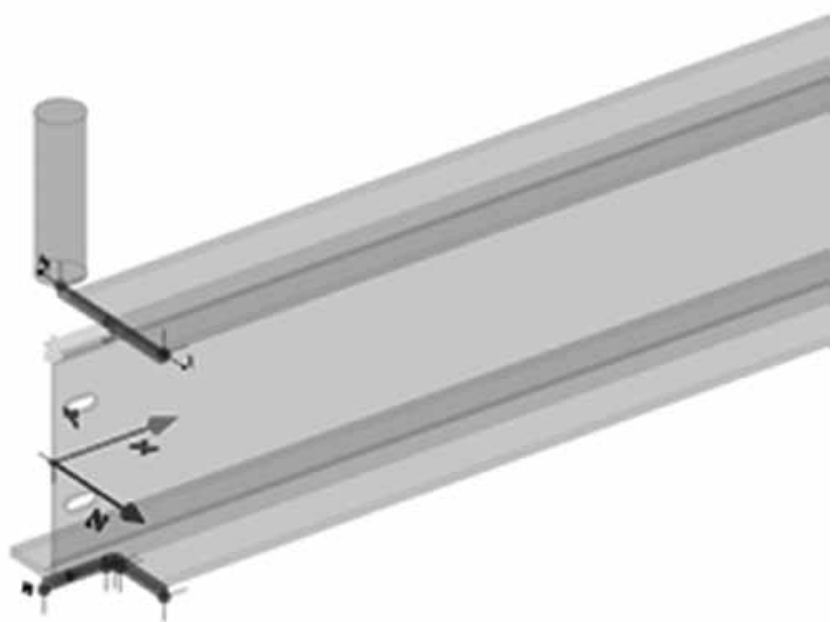

Rys. 6. Wizualizacja zaprogramowanego procesu cięcia plazmowego półek profilu [2]

Fig. 6. Visualisation of a programmed process of the plasma cut of the gantry shelves [2]

$\mathrm{Na}$ tym etapie kończą się operacje programowania związane z profilem głównym. Dalsze programowanie koncentruje się na elementach dokładanych do elementu głównego takich jak blachy czołowe, żebra itd. Każdy dokładany element jest traktowany indywidualnie i każdemu z osobna przydzielane są poszczególne operacje.

Pierwszą programowaną operacją jest przyporządkowanie magnesu za pomoca, którego będzie dokładany element do profilu głównego. W zależności

od kształtu, wielkości i ciężaru blachy, są do wyboru trzy rodzaje magnesów. Następnie ustala się pozycję magnesu względem blachy, sposób dołożenia i odejścia ramienia robota. Operacje te są na bieżąco wizualizowane w oknie podglądu (rys. 7).

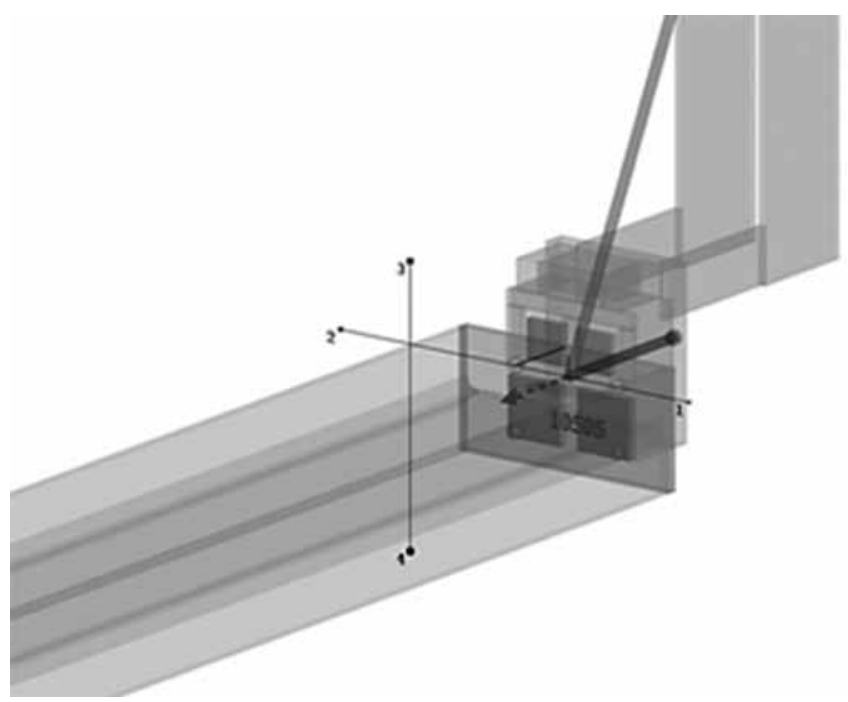

Rys. 7. Wizualizacja dołożenia blachy czołowej do profilu głównego [2] Fig. 7. Visualisation of adding the front sheet metal plate to the main gantry [2]

Następnym krokiem jest programowanie spoin sczepnych między przyłożoną blachą, a profilem (rys.8). Program automatycznie generuje dostępne linie do wykonania zczepów, lecz do programisty należy decyzja o miejscach ich wykonania. Może je zatwierdzić zgodnie z tym, co proponuje mu program lub ustalić je ręcznie.

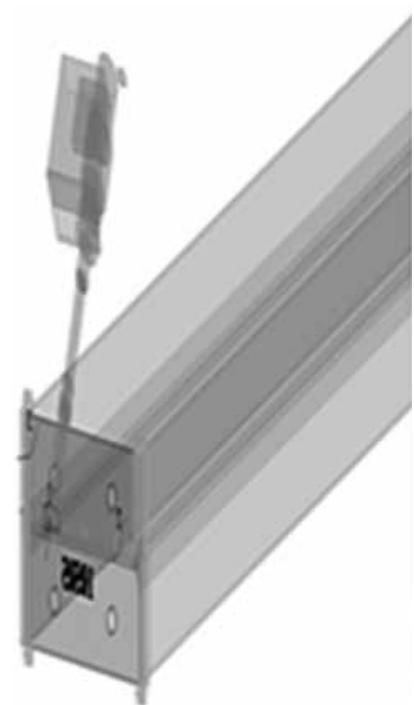

W zależności od potrzeb można także zaprogramować podgrzewanie wstępne, między ściegowe czy końcowe, do którego wykorzystuje się palnik gazowy. Tutaj zadaje się m.in. takie parametry jak czas i miejsce podgrzewania.
Rys. 7. Wizualizacja umiejscowienia zczepów [2]

Fig. 7. Visualisation of locating tacking points [2] 
Końcowym zadaniem, jakie trzeba wykonać jest programowanie spawania. Pierwszą czynnością jest automatyczne wygenerowanie przez program wszystkich możliwych miejsc do położenia spoin łączących elementy. Następnie programista dokonuje wyboru, które spoiny będą dopuszczone i określa sposób ustawienia palnika i kolejność spawania. Kolejnym elementem jest określenie wielkości spoin, zgodnych z projektem. Położenie każdej spoiny musi być poprzedzone pomiarem i ustaleniem przez urządzenie rzeczywistych kątów i odstępów między elementami. W tym celu zadaje się odpowiedni sposób pomiaru w zależności od zaplanowanej spoiny i miejsca jej położenia:

- pomiar dla spoiny pachwinowej,

- pomiar dla spoiny czołowej,

- mierzenie zakończeń na półce (na grubości elementu),

- mierzenie w miejscu ustalonym przez programistę.

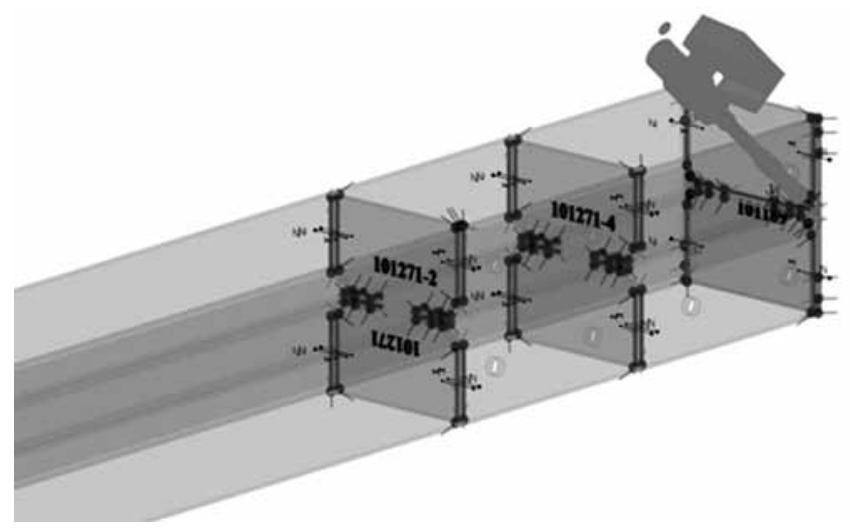

Rys. 9. Wizualizacja zaprogramowanego procesu spawania [2] Fig. 9. Visualisation of a programmed welding process [2]

Po wykonaniu powyższych kroków programowania programujący urządzenie przechodzi do okna „Przeglądu operacji”, gdzie znajduje się wykaz wszystkich operacji, które zostaną wykonane przez SBA. W tym miejscu można sprawdzić ich kolejność i dokonywać korekt programu np. zmiana kolejności montażu, podgrzewania czy spawania. W oknie tym widzimy także podział pracy poszczególnych robotów (Master/Slave) i przydzielonych im zadań, co zostało pokazane na rysunku 10, gdzie z lewej strony są wyszczególnione operacje dla każdego robota, natomiast w prawym oknie jest zobrazowany zakres ich działania. Programista ma też możliwość automatycznej optymalizacji pracy urządzenia, gdzie program sam ustala kolejność wszystkich operacji. W tym miejscu kończy się programowanie w trybie edycji.

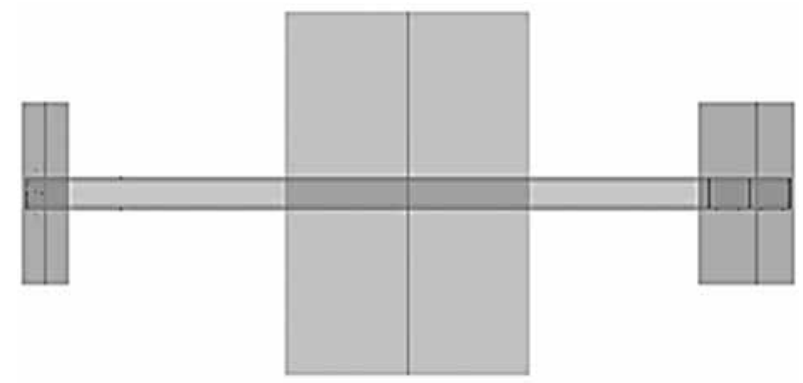

Rys. 10. Podział pracy robotów w oknie „Przeglądu operacji” [2] Fig. 10. Division of the robots' labour in the 'Object explorer' window [2]
Po wyjściu z trybu edycji programista w zakładce „Produkcja i generowanie produkcji” uzyskuje informacje o poprawności wykonania programu (rys. 11). Można tu odczytać następujące informacje:

- o wygenerowaniu programu,

- spełnieniu wymogów elementu głównego (dot. wymiarów i rodzaju profilu),

- prawidłowości ustawienia portali,

- prawidłowym ustaleniu punktu „0”,

- spełnieniu wymogów wymiarowych dokładanych elementów, np. blach,

- prawidłowym podziale pracy pomiędzy robotami (Master/Slave),

- optymalizacji spawania.

W środkowej części (rys. 11) znajdują się dwie tabele, z których jedna dotyczy fazy montażowej, a druga fazy spawalniczej. W tabelach tych uwzględnione są wszystkie dokładane elementy i operacje, które zostaną na nich wykonane. Program sprawdza poprawność każdej operacji. W przypadku poprawnego wykonania programu danej czynności, komórka odnosząca się do niej, podświetlana jest w tabeli kolorem zielonym z opisem „ok.", natomiast w przypadku nieprawidłowości, dana komórka wyświetla się w kolorze czerwonym z opisem „nok”. Po wyborze takiej komórki (kolor niebieski) w prawym górnym rogu wyświetla się opis niezgodności, którą należy poprawić np. kolizja palnika, bądź niewłaściwe umiejscowienie magnesu na dokładanym elemencie.

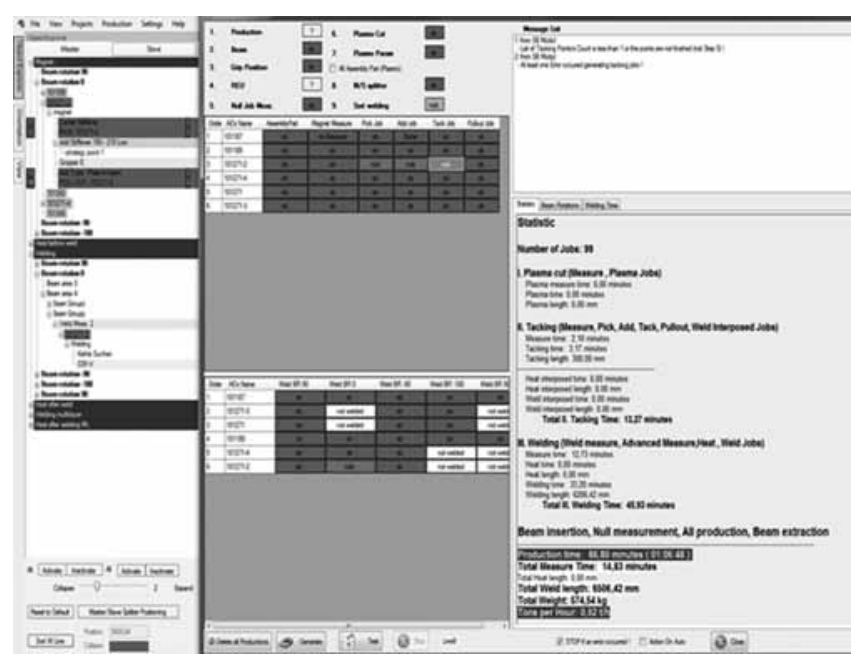

Rys. 11. Okno „Produkcji i generowania produkcji” [2]

Fig. 11. 'Production and generating production' window [2]

W prawym dolnym rogu znajduje się cała statystyka wykonania programu przez urządzenie SBA. Znajdziemy tutaj informacje o ilości operacji, czasie ich wykonania z podziałem na narzędzia, całkowitym czasie produkcji oraz wyliczeniem wydajności w godzinach na tonę.

Po sprawdzeniu i wyeliminowaniu wszystkich niezgodności program zostaje wygenerowany i za pomocą sieci komputerowej zapisany w pamięci komputera SBA. 


\section{Zasada działania}

Cały proces produkcyjny zaczyna się od zweryfikowania dostarczonej dokumentacji wykonawczej konstrukcji stalowej pod kątem możliwości wykorzystania urządzenia SBA do jej wytworzenia. Wtedy to, technolog odpowiedzialny za optymalne wykorzystanie urządzenia podejmuje decyzję o tym czy dana partia produkcji, czy też pojedynczy element może być wyprodukowany przy pomocy SBA, bądź w tradycyjny sposób przez monterów i spawaczy. $\mathrm{Na}$ decyzję taką wpływa wiele różnorodnych czynników wynikających z możliwości, zakresu zastosowania maszyny, a także obciążenia produkcyjnego i terminów dostaw uzgodnionych ze zleceniodawcami. Pierwszym z nich jest rodzaj konstrukcji i zastosowanych w niej profili głównych, które są możliwe do wykorzystania przez SBA (opisane w rozdziale, Zakres zastosowania"). Następnym czynnikiem do rozpatrzenia jest stopień złożoności konstrukcji i ograniczenia z tego wynikające. Nie wszystkie rozwiązania zaproponowane przez projektantów ze względu na ich skomplikowanie są możliwe do zrealizowania przez urządzenie (rozdział "Ograniczenia i bariery").Kolejnym aspektem, który trzeba wziąć pod uwagę jest konieczność dotrzymania terminów dostaw gotowej konstrukcji. W przypadku pełnego obciążenia produkcyjnego urządzenia, część produkcji wykonywana jest równolegle tradycyjnymi sposobami.

Po weryfikacji, zatwierdzeniu i przydzieleniu danej partii elementów konstrukcji do produkcji przez SBA następuje etap programowania urządzenia przy pomocy programu Pro-FIT, opisany szczegółowo w rozdziale "Proces programowania".

Właściwy proces produkcji rozpoczyna się od wprowadzenia przygotowanego w biurze technologicznym programu do komputera SBA. Następnie operator za pomocą suwnicy nakłada wcześniej przygotowany profil bądź profile główne na stół załadunkowy oraz elementy dodatkowe np. blachy, kątowniki itd. na stół załadunkowy do blach. W tym miejscu warto wspomnieć o przygotowaniu elementów przeznaczonych do montażu i spawania przez zrobotyzowane stanowiska, które powinny być wykonane $w$ dużej tolerancji wymiarowej, ze względu na dokładność montażu. W tym celu należy stosować wysokiej klasy urządzenia, które zapewnią odpowiednią jakość i dokładność np.: wypalarki laserowe lub plazmowe $\mathrm{w}$ przypadku blach, oraz piłowiertarki w przypadku profili.

Po nałożeniu profilu głównego na stół załadunkowy jest on za pomocą przenośnika poprzecznego taśmowego przenoszony na samotok, który transportuje go do portali chwytających. Podczas transportu samotokiem profil jest dokładnie mierzony za pomocą skanera laserowego $i$ jest odnajdowany punkt "0" na belce, służący jako baza do dalszych operacji. Portale chwytająco - pozycjonujące za pomocą siłowników unieruchamiają profil w zaprogramowanych wcześniej miejscach. Po tej operacji robot głównego portalu spawalniczego za pomocą skanera laserowego umiejscowionego na palniku spawalniczym dokonuje pomiaru profilu głównego w celu odnalezienia miejsca cięcia (gdy jest ono wymagane). Mierzenie poprzedza każdą operacje wykonywaną przez roboty czyli cięcie plazmowe, podgrzewanie czy spawanie. Wykonuje się go w celu odnalezienia dokładnych wymiarów profilu, gdyż jak wiadomo profile są produkowane $\mathrm{w}$ różnej tolerancji. Po dokonaniu pomiaru robot pobiera z zasobnika narzędzi palnik plazmowy i wykonuje cięcie bądź ukosowanie.

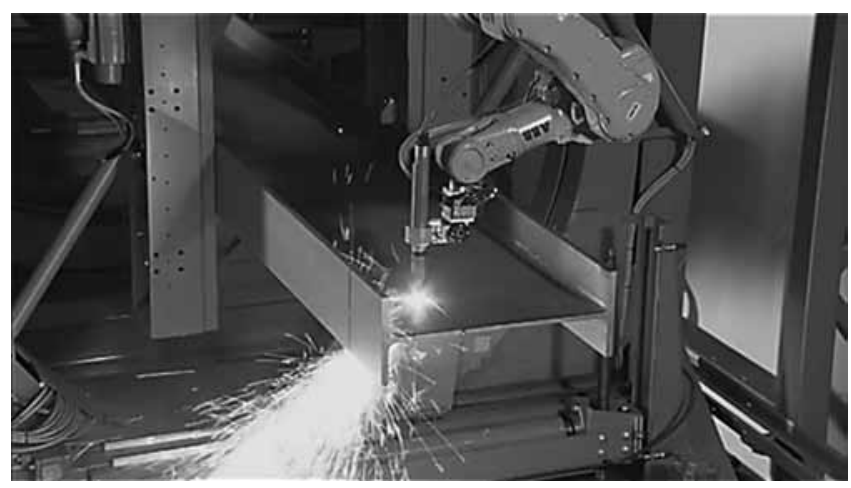

Rys. 12. Cięcie palnikiem plazmowym [1]

Fig. 12. Cutting by the plasma welding torch [1]

W razie potrzeby profil może być obrócony wokół własnej osi (oś x), a umożliwia to konstrukcja portali chwytających.

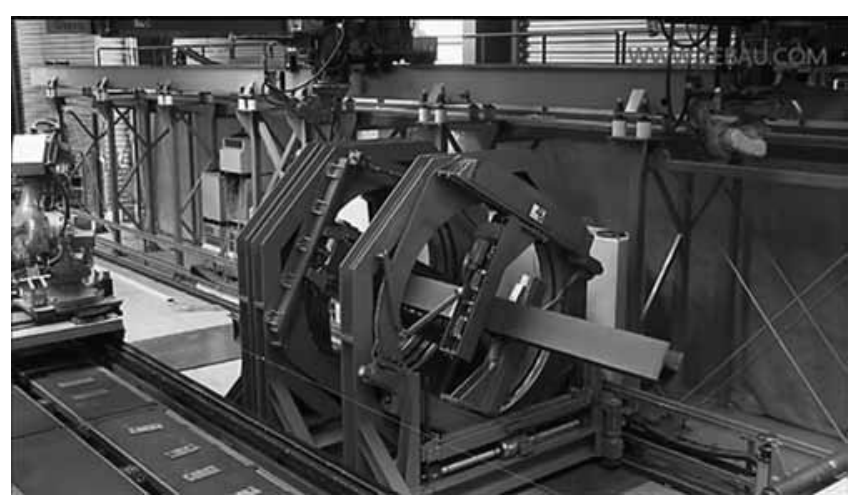

Rys. 13. Portale chwytająco-pozycjonujące w trakcie obracania profilu [1]

Fig. 13. Gripping-positioning gantries while rotating the profile [1]

W tym samym czasie znajdujące się na stole załadunkowym blachy transportowane są $\mathrm{w}$ rejon pracy robota dokładającego elementy. Podczas transportu blachy są skanowane skanerem laserowym AMBO w celu rozpoznania ich kształtu, natomiast pomiaru ich grubości dokonuje specjalna kamera. Dane te razem z miejscem i pozycją położenia blach na stole są zapisywane w pamięci komputera. 


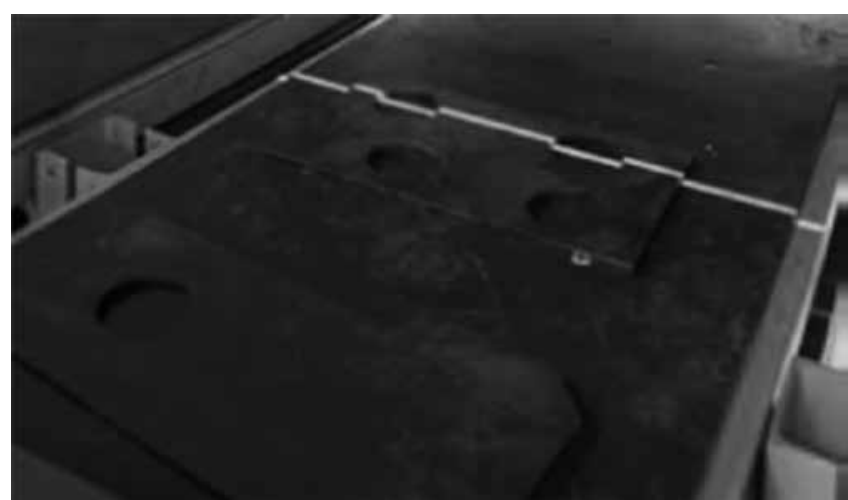

Rys. 14. Skanowanie blach [1]

Fig. 14. Scanning sheet metal plates [1]

Następny etap to dokładanie blach do profilu głównego zgodnie z zaprogramowaną kolejnością. W pierwszej kolejności robot portalu głównego lub pomocniczego dokonuje pomiaru miejsca montażu blachy, następnie robot dokładający elementy pobiera z zasobnika odpowiedni magnes $w$ zależności od ciężaru i wymiarów blachy. Są trzy rodzaje magnesów:

- dla blach do $20 \mathrm{~kg}$ i wymiarach do $180 \times 220$ × 120 $\mathrm{mm}$,

- dla blach od 10 do100 kg o wymiarach do $270 \times 220$ $\mathrm{x} 140 \mathrm{~mm}$,

- dla blach od 50 do $200 \mathrm{~kg}$ o wymiarach do 700 × 220 $\mathrm{mm}$.

Po pobraniu magnesu robot wykorzystując dane ze skanowania blach odnajduje i podnosi pożądany element, następnie dokłada go do profilu głównego. W tym momencie do pracy przystępuje robot spawalniczy, który wykonuje zczepy. Po zamocowaniu danej blachy robot montujący wyłącza magnes i pobiera kolejną blachę. Sytuacja powtarza się do momentu zamontowania wszystkich elementów. Zdarzają się sytuacje kiedy blachy na stole ułożone są odwrotnie. W tym przypadku robot umieszcza daną blachę w specjalnie do tego celu skonstruowanego urządzenia do obracania blach, które przytrzymuje ją w hydraulicznej szczęce do momentu przechwycenia jej z drugiej strony przez magnes robota.

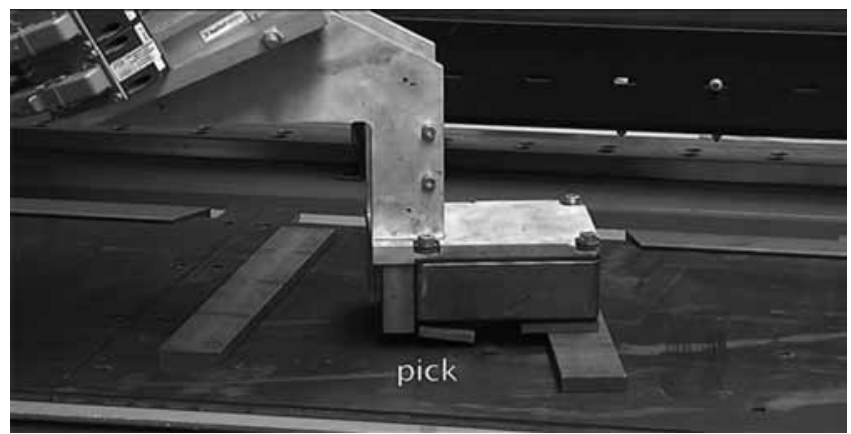

Rys. 15. Podnoszenie blachy ze stołu załadowczego przez ramię robota za pomocą magnesu [1]

Fig. 15. Picking a sheet metal plate from the loading table by the robot's arm using the magnet [1]

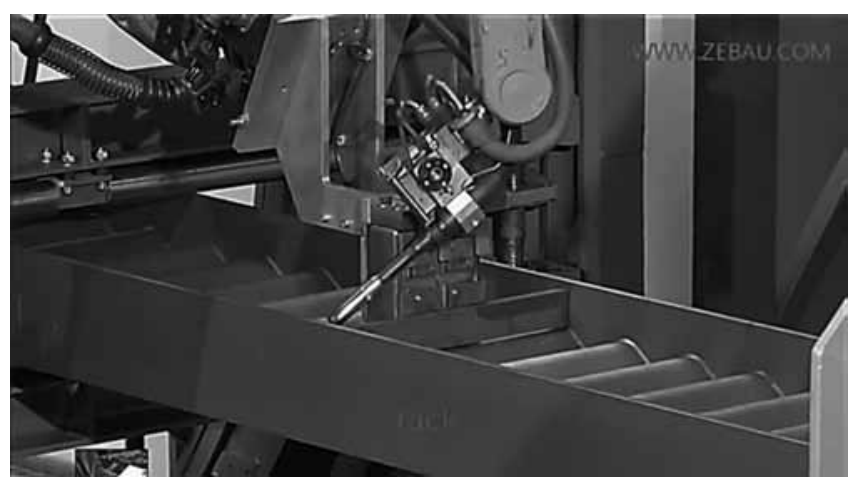

Rys. 16. Dołożenie blachy do kształtownika i sczepianie [1]

Fig. 16. Adding a sheet metal plate to the profile and tacking [1]

Po zamontowaniu wszystkich elementów oba roboty spawalnicze przystępują do spawania wszystkich posczepianych elementów. Spawanie każdego elementu poprzedza operacja mierzenia. Po wykonaniu spawania gotowy element wyjeżdża na specjalnym przenośniku z portali chwytających. Na tym zadaniu SBA kończy pracę.

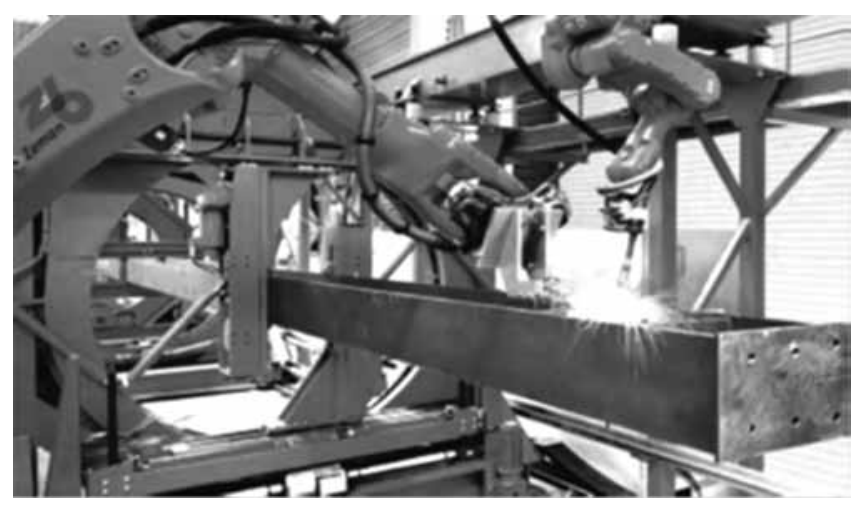

Rys. 17. Spawanie dołożonej blachy [1]

Fig. 17. Welding an added sheet metal plate [1]

Ogólną zasadą, w celu optymalnego wykorzystania urządzenia jest zamontowanie w pierwszej kolejności wszystkich elementów, dopiero później następuje ich spawanie. Zdarzają się jednak sytuacje, kiedy trzeba zmienić kolejność. W przypadku, gdy blachy (np. żebra) są blisko siebie i po ich zamontowaniu nie będzie miejsca na uchwyt spawalniczy, wtedy spawanie następuje pomiędzy montażem kolejnych blisko położonych siebie blach.

SBA dysponuje także narzędziem do kalibracji uchwytu spawalniczego. W momencie kiedy spoiny odbiegają od wymaganych norm lub kiedy skaner laserowy umieszczony na palniku wykonuje nieprawidłowe pomiary, operator może zlecić maszynie kalibrację palnika. Kalibracja polega na tym, że ramię robota z zamocowanym palnikiem dojeżdża do zaostrzonego na końcu trzpienia. Operacja ta odbywa się automatycznie przy pomocy sensorów optycznych i kończy się w momencie, kiedy drut elektrodowy wychodzący z uchwytu spawalniczego idealnie pokrywa się z zaostrzoną końcówką trzpienia (rys. 18). 


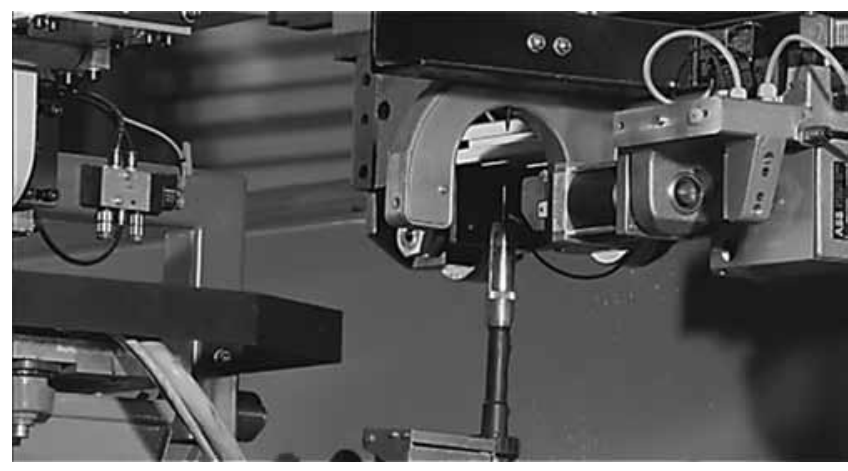

Rys. 18. Kalibrowanie uchwytu spawalniczego [1]

Fig. 18. Calibrating a welding holder [1]

Kolejną funkcją jaką posiada SBA jest samoczyszczenie łuski uchwytu spawalniczego. W przypadku zaburzenia przepływu gazu osłonowego $\mathrm{z}$ powodu nagromadzenia się odprysków na łusce uchwytu spawalniczego, palnik ten zostaje umieszczony w specjalnym urządzeniu, które za pomocą niewielkiego frezu oczyszcza łuskę, a następnie natryskuje ją preparatem antyodpryskowym.

\section{Parametry i zakres zastosowania}

Steel Beam Assembler ma szeroki zakres zastosowania dzięki budowie i możliwościom zastosowanych w niej urządzeń. Wykorzystanie potencjału robotów spawalniczych połączonych z wysokiej klasy źródłem prądu pozwala na wykonanie ogromnej większości spoin wymaganych w dokumentacji danego elementu. Natomiast przemyślana budowa SBA pozwala na wykorzystanie do produkcji szerokiego wachlarza profili stalowych.

\section{Parametry SBA}

Wymiary:

- długość - 62000mm,

- szerokość - $13500 \mathrm{~mm}$,

- wysokość - $6000 \mathrm{~mm}$,

- przestrzeń robocza - szer. 1630 mm, wys. 1380 $\mathrm{mm}$,

- prędkość przenoszenia elementów - $v=20 \mathrm{~m} / \mathrm{min}$. Rodzaje możliwych do zastosowania profili:

- dwuteownikiwalcowane nagorąco: HEA, HEB, HEM, IPE, HD;

- kształtowniki zamknięte kwadratowe i prostokątne wykonane na gorąco;

- kształtowniki zamknięte kwadratowe i prostokątne profilowane na zimno;

- blachownice spawane: IKS, HKS, IPBS oraz niestandardowe;

- belki specjalne: dwuteowniki ze średnikiem falistym SIN
Wymiary profili możliwych do prefabrykacji:

- długość profilu - min. 3000 mm / max. 16000 mm,

- wysokość profilu - min. $200 \mathrm{~mm} / \max .1560 \mathrm{~mm}$,

- szerokość profilu - min. $100 \mathrm{~mm} / \mathrm{max} .500 \mathrm{~mm}$,

- masa profilu nieuzbrojonego - max.do $6000 \mathrm{~kg}$,

- masa profilu uzbrojonego - max.do $8000 \mathrm{~kg}$.

Rodzaje elementów możliwych do zamontowania do profilu głównego:

- blachy,

- kątowniki,

- dwuteowniki.

Maksymalna masa montowanych części wynosi $200 \mathrm{~kg}$.

Parametry robota dokładającego elementy IRB 6640 firmy $A B B$ :

- ramię robota.- przegubowe6-cio osiowe,

- udźwig - $235 \mathrm{~kg}$,

- zasięg - $2550 \mathrm{~mm}$,

- prędkość ruchu - 1,5 m/s,

- droga przesuwu w osi podłużnej - 17500 mm,

- wysokość podnoszenia - $1800 \mathrm{~mm}$.

Parametry robotówspawalniczych IRB 140 firmy ABB:

- ramię robota - przegubowe 6-cio osiowe;

- udźwig - 6 kg;

- zasięg - $810 \mathrm{~mm}$;

- trzy osie ruchu zewnętrznego prędkość - 1,5 m/s;

- droga przesuwu w osiach:

- oś x - $17500 \mathrm{~mm}$,

- oś y- $2000 \mathrm{~mm}$,

- oś z - $1600 \mathrm{~mm}$.

Parametry spawania:

- metoda spawania - MAG 135 (metal activegas);

- drut spawalniczy - G3Si1;

- gaz osłonowy - M21 (82\% Ar; 18\% CO2);

- rozmiary spoiny: - jednościegowe (a3 - a6),

- wielościegowe (a8, a10, a12, a15);

- prędkość spawania - max. do $1 \mathrm{~m} / \mathrm{min}$;

- źródło spawania - TransPulsSynergic 5000 firmy Fronius;

- prąd spawania - 3 - $500 \mathrm{~A}$;

- napięcie pracy - 14,2 - 39,0 V;

- masa - $38 \mathrm{~kg}$.

Laserowy system pomiarowy:

- szybkość skanowania - $300 \mathrm{~mm} / \mathrm{s}$,

- szerokość skanowania - 2 × $800 \mathrm{~mm}$,

- tolerancja skanowania - +/- $1 \mathrm{~mm}$. [7]

\section{Zdolność produkcyjna}

\section{Porównanie prędkości}

tradycyjnej produkcji konstrukcji do możliwości SBA

Wprowadzenie SBA do produkcji pozwala zaoszczędzić do $85 \%$ czasu wytwarzania konstrukcji stalowych w porównaniu z tradycyjnymi metodami, a obniżenie roboczogodzin wiąże się z niższymi kosztami energii imagazynowania. Odnosząc to zdolnościprodukcyjnej, 
która wynosi ok. 300 Mg/miesiąc łatwo wyliczyć korzyści płynące z zastosowania SBA.

Poniżej przedstawione są przykładowe porównania czasów pomiędzy produkcją wykonywaną przez SBA, a tradycyjnym ręcznym sposobem wytwarzania standardowych elementów wykorzystanych w konstrukcjach.

Przykład elementu zbudowanego z profilu gorąco walcowanego HEA 400, który ma zamontowane i przyspawane 14 blach, o masie całkowitej $0,844 \mathrm{Mg}$ (rys. 19), oraz tabela porównawcza.

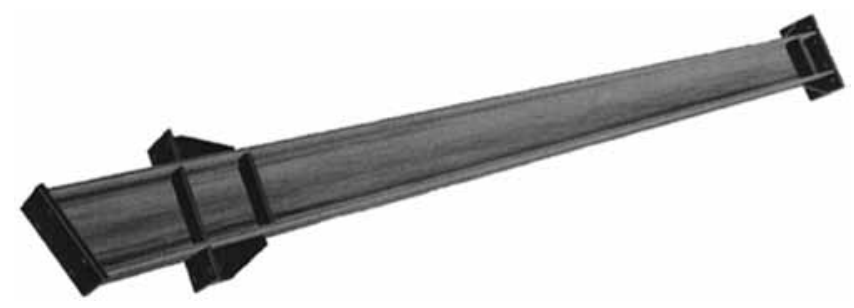

Rys. 19. Profil HEA $400 \mathrm{z}$ uzbrojeniem [1]

Fig. 19. Armed HEA 400 profile [1]

\begin{tabular}{|c|c|c|c|c|c|}
\hline & \multicolumn{2}{|c|}{ Ręcznie } & \multicolumn{2}{c|}{ SBA } & Oszczędność \\
\hline $\begin{array}{c}\text { Czas } \\
\text { montażu }\end{array}$ & $\begin{array}{c}100 \\
\text { min. }\end{array}$ & $\begin{array}{c}1,97 \\
\mathrm{~h} / \mathrm{Mg}\end{array}$ & $\begin{array}{c}14,00 \\
\mathrm{~min} .\end{array}$ & $\begin{array}{c}0,35 \\
\mathrm{~h} / \mathrm{Mg}\end{array}$ & $86 \%$ \\
\hline $\begin{array}{c}\text { Czas } \\
\text { spawania }\end{array}$ & $\begin{array}{c}120 \\
\text { min. }\end{array}$ & $\begin{array}{c}2,37 \\
\mathrm{~h} / \mathrm{Mg}\end{array}$ & $\begin{array}{c}67,20 \\
\mathrm{~min} .\end{array}$ & $\begin{array}{c}1,32 \\
\mathrm{~h} / \mathrm{Mg}\end{array}$ & $41 \%$ \\
\hline $\begin{array}{c}\text { Czas } \\
\text { obsługi }\end{array}$ & $\begin{array}{c}\text { włą- } \\
\text { czony }\end{array}$ & - & $\begin{array}{c}3,50 \\
\mathrm{~min} .\end{array}$ & $\begin{array}{c}0,07 \\
\mathrm{~h} / \mathrm{Mg}\end{array}$ & włączony \\
\hline Suma & $\begin{array}{c}220 \\
\text { min. }\end{array}$ & $\begin{array}{c}4,34 \\
\mathrm{~h} / \mathrm{Mg}\end{array}$ & $\begin{array}{c}84,70 \\
\mathrm{~min} .\end{array}$ & $\begin{array}{c}1,74 \\
\mathrm{~h} / \mathrm{Mg}\end{array}$ & $61 \%$ \\
\hline
\end{tabular}

Kolejny przykład to kształtownik spawany ze środnikiem falistym WTA 500 uzbrojony dwudziestoma siedmioma blachami o masie całkowitej $0,51 \mathrm{Mg}$ (rys. 20).

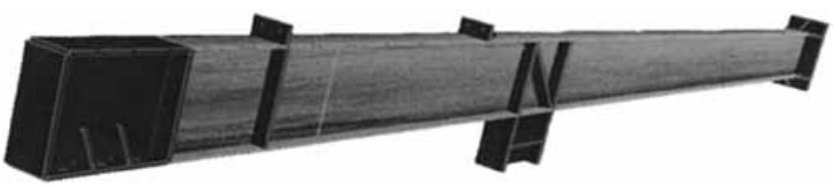

Rys. 20. Kształtownik WTA 500 z uzbrojeniem [1]

Fig. 20. Armed WTA 500 section [1]

\begin{tabular}{|c|c|c|c|c|c|}
\hline & \multicolumn{2}{|c|}{ Ręcznie } & \multicolumn{2}{c|}{ SBA } & Oszczędność \\
\hline $\begin{array}{c}\text { Czas } \\
\text { montażu }\end{array}$ & $\begin{array}{c}200 \\
\mathrm{~min} .\end{array}$ & $\begin{array}{c}6,54 \\
\mathrm{~h} / \mathrm{Mg}\end{array}$ & $\begin{array}{c}27,00 \\
\mathrm{~min} .\end{array}$ & $\begin{array}{c}0,88 \\
\mathrm{~h} / \mathrm{Mg}\end{array}$ & $86 \%$ \\
\hline $\begin{array}{c}\text { Czas } \\
\text { spawania }\end{array}$ & $\begin{array}{c}170 \\
\mathrm{~min} .\end{array}$ & $\begin{array}{c}5,55 \\
\mathrm{~h} / \mathrm{Mg}\end{array}$ & $\begin{array}{c}96,00 \\
\mathrm{~min} .\end{array}$ & $\begin{array}{c}3,14 \\
\mathrm{~h} / \mathrm{Mg}\end{array}$ & $44 \%$ \\
\hline $\begin{array}{c}\text { Czas } \\
\text { obsługi }\end{array}$ & $\begin{array}{c}\text { włą- } \\
\text { czony }\end{array}$ & - & $\begin{array}{c}3,50 \\
\mathrm{~min} .\end{array}$ & $\begin{array}{c}0,11 \\
\mathrm{~h} / \mathrm{Mg}\end{array}$ & włączony \\
\hline Suma & $\begin{array}{c}370 \\
\text { min. }\end{array}$ & $\begin{array}{c}12,09 \\
\mathrm{~h} / \mathrm{Mg}\end{array}$ & $\begin{array}{c}126,50 \\
\mathrm{~min} .\end{array}$ & $\begin{array}{c}4,13 \\
\mathrm{~h} / \mathrm{Mg}\end{array}$ & $66 \%$ \\
\hline
\end{tabular}

Profil gorąco walcowany IPE 240 i uzbrojenie w postaci 9 blach o masie całkowitej 0,206 Mg. (rys. 21).

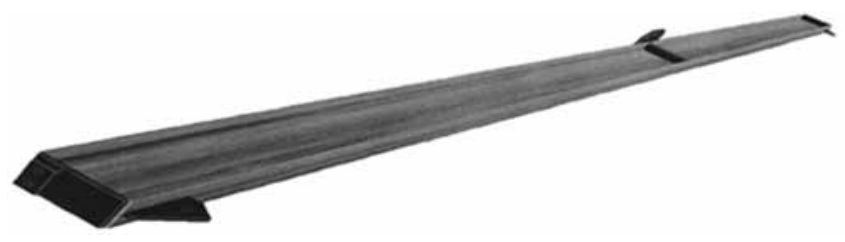

Rys. 21. Profil IPE $240 \mathrm{z}$ uzbrojeniem [1]

Fig. 21. Armed IPE 240 profile [1]

\begin{tabular}{|c|c|c|c|c|c|}
\hline & \multicolumn{2}{|c|}{ Ręcznie } & \multicolumn{2}{c|}{ SBA } & Oszczędność \\
\hline $\begin{array}{c}\text { Czas } \\
\text { montażu }\end{array}$ & $\begin{array}{c}60 \\
\mathrm{~min} .\end{array}$ & $\begin{array}{c}4,85 \\
\mathrm{~h} / \mathrm{Mg}\end{array}$ & $\begin{array}{c}9,00 \\
\mathrm{~min} .\end{array}$ & $\begin{array}{c}0,73 \\
\mathrm{~h} / \mathrm{Mg}\end{array}$ & $85 \%$ \\
\hline $\begin{array}{c}\text { Czas } \\
\text { spawania }\end{array}$ & $\begin{array}{c}40 \\
\mathrm{~min} .\end{array}$ & $\begin{array}{c}3,24 \\
\mathrm{~h} / \mathrm{Mg}\end{array}$ & $\begin{array}{c}22,00 \\
\mathrm{~min} .\end{array}$ & $\begin{array}{c}1,78 \\
\mathrm{~h} / \mathrm{Mg}\end{array}$ & $45 \%$ \\
\hline $\begin{array}{c}\text { Czas } \\
\text { obsługi }\end{array}$ & $\begin{array}{c}\text { włą- } \\
\text { czony }\end{array}$ & - & $\begin{array}{c}3,50 \\
\mathrm{~min} .\end{array}$ & $\begin{array}{c}0,28 \\
\mathrm{~h} / \mathrm{Mg}\end{array}$ & włączony \\
\hline Suma & $\begin{array}{c}100 \\
\text { min. }\end{array}$ & $\begin{array}{c}8,09 \\
\mathrm{~h} / \mathrm{Mg}\end{array}$ & $\begin{array}{c}34,50 \\
\mathrm{~min} .\end{array}$ & $\begin{array}{c}2,79 \\
\mathrm{~h} / \mathrm{Mg}\end{array}$ & $66 \%$ \\
\hline
\end{tabular}

IPE500 uzbrojony w 9 blach o masie całkowitej 0,612 Mg. (rys. 22).

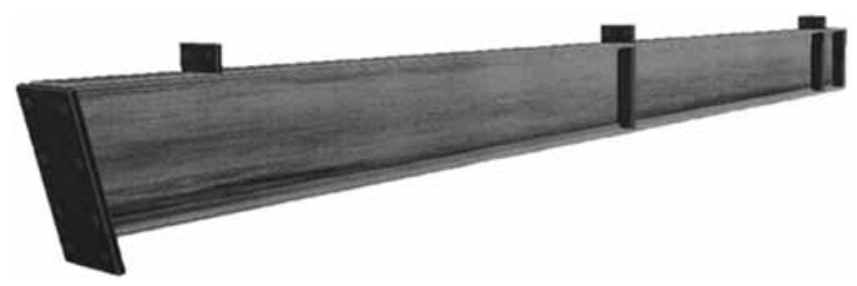

Rys. 22. Profil IPE $500 \mathrm{z}$ uzbrojeniem [1]

Fig. 22. Armed IPE 500 profile [1]

\begin{tabular}{|c|c|c|c|c|c|}
\hline & \multicolumn{2}{|c|}{ Ręcznie } & \multicolumn{2}{c|}{ SBA } & Oszczędność \\
\hline $\begin{array}{c}\text { Czas } \\
\text { montażu }\end{array}$ & $\begin{array}{c}70 \\
\text { min. }\end{array}$ & $\begin{array}{c}1,91 \\
\text { h/Mg }\end{array}$ & $\begin{array}{c}9,00 \\
\text { min. }\end{array}$ & $\begin{array}{c}0,25 \\
\text { h/Mg }\end{array}$ & $87 \%$ \\
\hline $\begin{array}{c}\text { Czas } \\
\text { spawania }\end{array}$ & $\begin{array}{c}70 \\
\text { min. }\end{array}$ & $\begin{array}{c}1,91 \\
\text { h/Mg }\end{array}$ & $\begin{array}{c}38,40 \\
\text { min. }\end{array}$ & $\begin{array}{c}1,05 \\
\text { h/Mg }\end{array}$ & $45 \%$ \\
\hline $\begin{array}{c}\text { Czas } \\
\text { obsługi }\end{array}$ & $\begin{array}{c}\text { włą- } \\
\text { czony }\end{array}$ & - & $\begin{array}{c}3,50 \\
\text { min. }\end{array}$ & $\begin{array}{c}0,10 \\
\text { h/Mg }\end{array}$ & włączony \\
\hline $\begin{array}{c}\text { Suma } \\
140 \\
\text { min. }\end{array}$ & $\begin{array}{c}3,82 \\
\text { h/Mg }\end{array}$ & $\begin{array}{c}50,90 \\
\text { min. }\end{array}$ & $\begin{array}{c}1,40 \\
\text { h/Mg }\end{array}$ & $64 \%$ \\
\hline
\end{tabular}

Profil HEB 220 i uzbrojenie w postaci 29 blach o masie całkowitej 0,717 Mg. (rys. 23). Element częściowo spawany ręcznie (brak dostępu do wykonania spoin przez robota spawalniczego). 


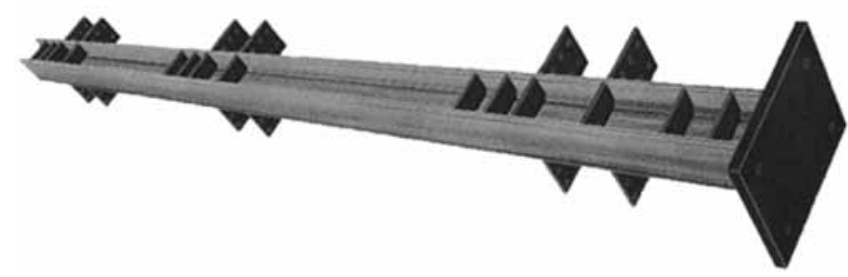

Rys. 23. Profil HEB $220 \mathrm{z}$ uzbrojeniem [1]

Fig. 23. Armed HEB 220 profile [1]

\begin{tabular}{|c|c|c|c|c|c|}
\hline & \multicolumn{2}{|c|}{ Ręcznie } & \multicolumn{2}{c|}{ SBA } & Oszczędność \\
\hline $\begin{array}{c}\text { Czas } \\
\text { montażu }\end{array}$ & $\begin{array}{c}200 \\
\text { min. }\end{array}$ & $\begin{array}{c}4,65 \\
\mathrm{~h} / \mathrm{Mg}\end{array}$ & $\begin{array}{c}29,00 \\
\mathrm{~min} .\end{array}$ & $\begin{array}{c}0,67 \\
\mathrm{~h} / \mathrm{Mg}\end{array}$ & $85 \%$ \\
\hline $\begin{array}{c}\text { Czas } \\
\text { spawania }\end{array}$ & $\begin{array}{c}170 \\
\text { min. }\end{array}$ & $\begin{array}{c}3,95 \\
\mathrm{~h} / \mathrm{Mg}\end{array}$ & $\begin{array}{c}70,00 \\
\mathrm{~min} .\end{array}$ & $\begin{array}{c}1,63 \\
\mathrm{~h} / \mathrm{Mg}\end{array}$ & $44 \%$ \\
\hline $\begin{array}{c}\text { Czas } \\
\text { ręcznego } \\
\text { spawania }\end{array}$ & $\begin{array}{c}\text { włą- } \\
\text { czony }\end{array}$ & - & $\begin{array}{c}26,00 \\
\mathrm{~min} .\end{array}$ & $\begin{array}{c}0,60 \\
\mathrm{~h} / \mathrm{Mg}\end{array}$ & włączony \\
\hline $\begin{array}{c}\text { Czas } \\
\text { obsługi }\end{array}$ & $\begin{array}{c}\text { włą- } \\
\text { czony }\end{array}$ & - & $\begin{array}{c}3,50 \\
\mathrm{~min} .\end{array}$ & $\begin{array}{c}0,08 \\
\mathrm{~h} / \mathrm{Mg}\end{array}$ & włączony \\
\hline Suma & $\begin{array}{c}370 \\
\text { min. }\end{array}$ & $\begin{array}{c}8,60 \\
\mathrm{~h} / \mathrm{Mg}\end{array}$ & $\begin{array}{c}128,50 \\
\mathrm{~min} .\end{array}$ & $\begin{array}{c}2,98 \\
\mathrm{~h} / \mathrm{Mg}\end{array}$ & $64 \%$ \\
\hline
\end{tabular}

\section{Ograniczenia i bariery}

Urządzenie SBA jest nowością na rynku prefabrykacji konstrukcji stalowych. Rynek ten jest niezwykle różnorodny pod względem ilości produkowanych wszelkiego rodzaju profili stalowych, jak również niezliczonych rozwiązań konstrukcyjnych. Stworzenie maszyny, która mogłaby objąć swoim działaniem powyższe aspekty jest niezwykle trudne. Wynikają stąd pewne ograniczenia i bariery. Nad wyeliminowaniem części z nich już teraz trwają prace, lecz niektóre problemy wymagają dogłębniejszych analiz i nowych rozwiązań.

Ze względu na swoją konstrukcję SBA ma pewne ograniczenia wymiarowe wynikające $z$ przestrzeni roboczej, czyli elementy prefabrykowane muszą się mieścić w pewnych ramach (patrz rozdział „Parametry i zakres zastosowania"). Brak możliwości produkcji elementów, w których profilem głównym są rury okrągłe, ceowniki i kątowniki (prace nad ich wdrożeniem trwają). Kolejnym ograniczeniem są konstrukcje, w których zaprojektowano ułożone blisko siebie blachy, gdzie nie ma dostępu do ich zamontowania oraz wykonania spoin. Problemem może też być dokumentacja projektowa wykonana w programach 3D niekompatybilnych z oprogramowaniem ProFIT. Rozwiązaniem w tym przypadku jest przerobienie tej dokumentacji do właściwego programu. Dokumentacja projektowa konstrukcji, w której wymagane jest ukosowanie elementów, jest rysowana (zgodnie z zasadami) wykorzystując odnośniki z symbolami jak należy wykonać to ukosowanie (np. ukosowanie na $\mathrm{V}, \mathrm{X}, \mathrm{K}$ ). Oprogramowanie urządzenia nie odczytuje tych symboli i element traktowany jest jako nieukosowany, dlatego trzeba przerabiać dokumentację tak, aby zamiast symboli były faktycznie narysowane skosy, co wymaga większego nakładu pracy.

Jak wcześniej wspomniano maszyna SBA jest niedawno powstałą konstrukcją mająca swoje ograniczenia i bariery, ale cały czas trwają prace nad ich wyeliminowaniem i poszerzeniem zakresy działania.

\section{Kierunki rozwoju}

Urządzenie Steel Beam Assembler jest zbudowane w przemyślany sposób, tworząc tzw. konstrukcję "otwartą" tzn. można ją na bieżąco rozbudowywać i unowocześniać. Już teraz możliwy jest zakup urządzenia z podwójną stacją roboczą, tzn. są dwa niezależnie pracujące urządzenia, połączone wspólnym pulpitem sterującym i obsługiwane przez jednego robota dokładającego elementy umieszczonego pomiędzy nimi.

Ciągle trwają prace mające na celu poszerzenie oferty zastosowania większej ilości profili. Szczególnie zaawansowane są prace nad możliwością prefabrykacji rur okrągłych. W tym celu projektowane są nowe uchwyty przytrzymujące oraz technologie pozycjonowania i mierzenia rur, gdyż jak wiadomo trudniej w tym przypadku o określenie osi i punktów odniesienia. Istnieje ścisła współpraca i nadzór nad urządzeniem przez biuro konstrukcyjne producenta urządzenia, które na bieżąco wprowadza korekty i pomaga rozwiązywać powstałe problemy. Konstruktorzy SBA reagują także na wszystkie sugestie zarówno programujących jak i obsługujących maszynę. W ten sposób urządzenie ciągle się rozwija i unowocześnia, a obsługa staje się prostsza.

Rozwój SBA jest prowadzony jednocześnie w trzech kierunkach:

- optymalizowanie działania,

- poszerzenie zakresu stosowanych profili,

- rozbudowa i uproszczenie programowania.

Optymalizowanie działania urządzenia wiąże się $z$ dodawaniem nowych funkcji i wprowadzaniem innowacyjnych elementów konstrukcyjnych w celu przyspieszenia wytwarzania konstrukcji stalowych oraz zwiększenia niezawodności maszyny.

Poszerzenie zakresu możliwych do wykorzystania profili związane jest z rozbudową niektórych ogniw maszyny np. nowa konstrukcja chwytaków do trzymania rur okrągłych.

Natomiast rozbudowa programu wynika bezpośrednio z rosnących możliwości SBA, a prace związane z uproszczeniem programu polegają na zautomatyzowaniu niektórych funkcji programu w celu skrócenia czasu jego wykonania. Przykładem mogą być prowadzone obecnie działania mające umożliwić powielanie pewnych fragmentów programu w przypadku powtarzających się elementów konstrukcji. Obecnie każdy dokładany, a następnie spawany element, nawet powtarzający się (np. żebra w belce) musi być z osobna programowany. Uproszczenie, nad którym się pracuje ma spowodować, że możliwe będzie jednorazowe zaprogramowanie czynności dla kilku identycznych elementów. 


\section{Podsumowanie}

Ideą stworzenia urządzenia było zminimalizowanie udziału człowieka przy wytwarzaniu, zwiększenie wydajności i jakości produkcji. Było to moźliwe dzięki nowoczesnym rozwiązaniom i zastosowaniu wysokiej klasy robotów, które są w stanie precyzyjnie i szybko zmontować oraz spawać elementy konstrukcji. Cały proces jest w pełni nadzorowany przez program kontrolny Pro-FIT powiązany z całą gamą czujników, które kontrolują wszystkie parametry urządzenia. Rola człowieka ogranicza się jedynie do zaprogramowania urządzenia i do nałożenia na stoły załadowcze komponentów takich jak $\mathrm{np}$. blachy czy profile walcowane oraz rozładunku gotowych elementów, natomiast reszta procesu dzieje się automatycznie.

W trakcie kilkuletniego funkcjonowania urządzenia można z całą odpowiedzialnością potwier- dzić jego zalety. Maszyna bez problemów spełniła wszystkie wymagania dopuszczające do wytwarzania konstrukcji stalowych, a ogromna ilość zrealizowanych projektów zakończyła się powodzeniem i zaowocowała brakiem reklamacji.

SBA może znaleźć bardzo szerokie zastosowanie w krajach rozwiniętych, w których wysokie koszty pracy spowodowały przeniesienie produkcji do krajów wschodnich. Dzięki swoim zaletom urządzenie może na powrót wznowić produkcję w tych krajach przy minimalnym zatrudnieniu i niskich kosztach. Natomiast w krajach mało rozwiniętych mających kłopoty z utrzymaniem wymaganych standardów ze względu na brak wykwalifikowanych pracowników zastosowanie urządzenia rozwiązuje ten problem i pozwala na podniesienie konkurencyjności na rynkach światowych $[3,4]$.

\section{Literatura}

[1] Materiały źródłowe firmy Zekon Sp. z o.o.

[2] Zrzut ekranu z programu Pro FIT.

[3] Nowak M., Buchowski J., Wiśniewski D.: Zrobotyzowane spawanie wielkogabarytowych elementów ze wspomaganiem oprogramowania off-line. Przegląd Spawalnictwa 2013, nr 10, s. 19-29.

[4] Słania J., Kuk Ł.: Proces łączenia materiałów do budowy pojazdów i nadwozi w przemyśle samochodowym. Przegląd Spawalnictwa 2014, nr 3, s. 40-46.

[5] Słania J., Dziędzioł R.: Automatyzacja i robotyzacja procesu montażu i spawania profili walcowanych - część 1 - historia. Przegląd Spawalnictwa 2015, nr 1.

\section{Przegląd Spawalnictwa Welding Technology Review Open Access Library}

Przegląd Spawalnictwa uruchomił możliwość wolnego dostępu do pełnych treści artykułów w ramach Open Access Library. Artykuły w języku angielskim w formacie PDF zamieszczane są na stronie internetowej redakcji: www.pspaw.pl.

Autorów zainteresowanych publikacją w Open Access Library prosimy o przesyłanie artykułów w języku polskim i angielskim. W miesięczniku nastąpi publikacja w języku polskim, a tekst w języku angielskim zostanie zamieszczony na stronie internetowej.

\section{ZAMÓW NEWSLETTER}

Zapraszamy Państwa do zapisania się na NEWSLETTER Przeglądu Spawalnictwa, w tym celu należy wysłać e-mail z tematem "NEWSLETTER"

na adres: redakcja@pspaw.pl 